\title{
DEVELOPMENT OF CREATIVITY AS A RESOURCE OF INNOVATIVE POTENTIAL OF PERSONALITY
}

\begin{abstract}
У статті представлено результати емпіричного дослідження, спрямованого на розвиток креативності як ресурсу інноваційного потенціалу особистості. Обгрунтовано, чому саме прицільним аналізом розвитку інноваційного потенціалу особистості обрано креативний компонент. Метою статті $\epsilon$ розкриття змісту та структури програми розвитку цього компоненту, а також висвітлення результатів ї апробації. Визначено п'ять послідовних етапів розвитку креативного компоненту інноваційного потенціалу (гіпотезування генерування - концептуалізація - оптимізація - реалізація), що визначають здатність особистості до створення, освоєння та впровадження нового. Відповідно до цих етапів окреслено завдання програми, яка передбачає орормування таких умінь: 1) самостійно виділяти, ставити й осмислювати проблемну ситуацію; 2) генерувати унікальні ідеї, що сприяють вирішенню визначеної проблеми по-новому; 3) здійснювати пошук концептуальної ідеї серед наявних із вирішення проблеми; 4) оцінювати наявні варіанти й оптимізувати вибір кращого варіанту розв'язку проблеми; 5) розробляти тактичний і стратегічний плани реалізації ідеї. Визначено зміст програми розвитку креативного компоненту інноваційного потенціалу майбутніх інженерів, що орокусувався на технічній творчості як конструктивно-технічній діяльності суб'єктів і включав такі розділи: «Інноваційно-творча спрямованість особистості»; «Технологіі індивідуального генерування інноваційних ідей»; «Концептуалізація інноваційних ідей»; «Формування базису прийняття інноваційних рішень»; «Комерціалізація результатів творчості». До кожного змістового розділу запропоновано підбирати вправи та завдання на розвиток різних мисленнєвих операцій. Емпірично доведено, що розроблена програма розвитку креативного компоненту інноваційного потенціалу особистості $є$ ефрективною.

Ключові слова: розвиток, інновачійний потенціал особистості, майбутні інженери, креативний компонент, програма.
\end{abstract}

The article presents the results of empirical research aimed at the development of creativity as a resource of the innovative potential of personality. It is substantiated why the creative component is chosen as the target analysis of the development of the innovative potential of personality. The purpose of the article is to reveal the content and structure of the development program of this component, as well as to highlight the results of its implementation. Five successive stages of development of the creative component of innovation potential (hypothesis - generation - conceptualization - optimization implementation) are defined, which determine the ability of an individual to create, master, and implement something new. In accordance with these stages, the task of the program is outlined, which provides for the formation of the following skills: 1) independently identify, pose and comprehend the problem situation; 2) generate unique ideas that help solve a particular problem in a new way; 3) to search for a conceptual idea among those available to solve the problem; 4) evaluate the available options and optimize the choice of the best solution to the problem; 5) develop tactical and strategic plans for the implementation of the idea. It is determined that the content of the program of development of the creative component of innovative potential of future engineers focused on technical creativity as constructive and technical activity of subjects, and included the following sections: "Innovative and creative orientation of personality"; "Technologies of an individual generation of innovative ideas"; "Conceptualization of innovative ideas"; "Formation of the basis for making innovative decisions"; "Commercialization of creative results". For each meaningful section, it is offered to select exercises and tasks for the development of specific mental operations. It is empirically proved that the proposed program for the development of the creative component of the innovative potential of a personality is effective.

Key words: development, innovative potential of personality, future engineers, creative component, program.
Постановка проблеми. Інноваційні процеси є неминучим викликом сьогодення, що висувають нові вимоги до психологічних якостей сучасної людини. Відповідно, дедалі більше науковців зосереджують увагу на такому феномені, як інноваційний потенціал особистості. Його пов'язують із прагненням до розвитку, відкритістю до нового, створенням чогось креативного, унікального, а також сприйняттям, освоєнням, поширенням і впровадженням інновацій на користь суспільства.
Відповідно, формування особистості з високим рівнем інноваційного потенціалу $є$ нагальним завданням сьогодення. Однак, як показує практика, дотепер не існує ефективної методики, яка пройшла би багаторічну апробацію. Тож особливий інтерес викликає дослідження того, яким чином слід розвивати інноваційний потенціал особистості.

Аналіз останніх досліджень і публікацій. Проблему розвитку інноваційного потенціалу особистості відображено в роботах таких 
дослідників: Т.Ю. Артюхової [8], К.В. Батовриної та М.С. Блохіної [10], Н Г. Котлярової [14], О.Б. Михайлової [15], О.О. Шмельової [20] та ін. У працях Т.О. Терехової та І.В. Пахно [17], О.С. Шемеліної та О.С. Бикової [19] запропоновано соціально-психологічні тренінги розвитку інноваційного потенціалу та інноваційних якостей особистості.

Постановка завдання. У попередній роботі [3] нами представлено психологічну структуру та ресурси інноваційного потенціалу особистості. Результати емпіричного дослідження його структурних компонентів (мотиваційного, когнітивного, креативного, емоційно-вольового та регулятивного) у студентів технічного університету дозволяють дійти висновку, що найменш розвиненим у потенційних інноваторів (тих студентів, котрі вважають себе інноваторами, але не мають високих досягнень у науково-інноваційній діяльності) $є$ саме креативний компонент, ресурсами якого $€$ творчий потенціал і радикалізм. Факторний аналіз показав, що найбільш вагомим фактором у структурі інноваційного потенціалу майбутніх інженерів $є$ радикалізм. 3 огляду на це вважаємо, що програму розвитку інноваційного потенціалу особистості доцільно спрямувати на розвиток креативного компоненту.

Креативний компонент у структурі інноваційного потенціалу займає особливе місце, адже забезпечує здатність особистості до створення та «породження» нового. Креативність розглядається нами як загальна творча здатність генерувати оригінальні ідеї, яка проявляється у різних сферах активності особистості, зокрема мисленні, спілкуванні, діяльності, та залежить від ії психологічних характеристик. Саме креативне мислення як здатність особистості вирішувати проблему новим способом «пробуджує» ідею у свідомості людини, яку можна як втілити у практику, так і не реалізувати.

Постановка завдання. Метою статті є розкриття змісту та структури програми розвитку креативного компоненту інноваційного потенціалу особистості, а також висвітлення результатів її апробації.

3 метою апробації запропонованої програми розвитку креативного компоненту інноваційного потенціалу особистості проведено формувальний експеримент, що здійснювався впродовж 2019-2020 рр. у КПІ ім. Ігоря Сікорського. Для проведення формувального експерименту сформовано дві групи студентів технічних профілів із першого по п'ятий курс навчання: 1) експериментальну - 24 особи; 2) контрольну - 24 особи.

Виклад основного матеріалу дослідження. В основу тренінгу покладено методологічне положення В.О. Моляко про те, що у дослідженні творчого процесу варто концентруватися на аналізі мисленнєвих процесів суб'єкта. «Щоб оволодіти вершинами творчості, необхідно здійснити і попередню підготовку - розвивати якості пам'яті, сприйняття, уяви, мислення, тобто треба бути досить підготовленим інтелектуально» [16, с. 38].

Оскільки програма розвитку інноваційного потенціалу більшою мірою розрахована на студентів як майбутніх фахівців в інженерній галузі (таких як інженер-технолог, інженер-механік, інженер-конструктор, інженер-дизайнер та ін.), то під час її розробки увага фокусувалася на технічній творчості як конструктивно-технічній діяльності суб'єктів, спрямованій на розвиток технічного мислення, здібностей до технічних видів діяльності, винахідництва.

Процес технічної творчості включає три взаємопов'язані цикли: 1) еталонування як розуміння умови задачі (оцінювання умови), за якого суб'єкт починає пошук розв'язку чи відмовляється від її розв'язання на основі оцінювання своїх можливостей; 2) проєктування як розроблення проєкту майбутньої конструкції (гіпотези чи задуму), на якому суб'єкт зазвичай приймає рішення про адекватність проєкту конструкції умовам задачі; 3) ескізування як попередній розв'язок і прогнозування остаточного результату, під час якого суб'єкт приймає рішення про ескізну побудову проєкту. Зауважимо, що «ці цикли не розділені між собою, а навпаки, перетікають один у другий, переплітаються» [16, с. 34].

Як визначено в [4], інноваційна діяльність тісно пов'язана із творчим аспектом: пошуком інформації, генеруванням ідей, прийняттям оригінальних рішень. Г.М. Кампосе наголошує на важливості креативного компоненту інноваційного потенціалу особистості: чим вищий рівень творчості, тим більше особистість здатна до інноваційної та підприємницької діяльності. 3 огляду на вищезазначене можна стверджувати, що цей компонент пронизує усі цикли інноваційної діяльності.

Можна зробити висновок, що творчим $€$ й інноваційний процес, який, за М. Басадуром [1; 2], включає чотири фази: 1) генерування; 2) концептуалізацію; 3) оптимізацію; 4) виконання. Саме ця ідея фазифікації покладана в основу запропонованого Т.О. Тереховою та І.В. Пахно соціально-психологічного тренінгу, спрямованого на розвиток інноваційного потенціалу особистості [17]. Автори тренінгу стверджують, що саме на фазі «генерування» завдяки актуалізації творчого потенціалу суб'єкта запускається цей інноваційний процес. Однак, на наш погляд, інноваційний процес розпочинається з висування суб'єктом гіпотези на основі власних спостережень у межах проблемної ситуації, достовірність 
якої потребує експериментальної перевірки (фаза «гіпотезування»).

Вищезазначене надало змогу запропонувати етапи розвитку креативного компоненту інноваційного потенціалу особистості: I етап гіпотезування - виявлення і визначення проблеми, пошук фактів, що підтверджують її існування; II етап - генерування - породження нових ідей, варіантів, які надають змогу вирішити проблему по-новому; III етап - концептуалізація - пошук ідей, серед наявних новітніх і нетрадиційних, із вирішення проблеми, тобто здійснення вибору з наявного переліку; IV етап - оптимізація - оцінювання ідей, формування критеріїв для пошуку та прийняття оптимального рішення; V етап - реалізація схвалення і втілення ідеї, планування дій, реалізація задуманого.

Виділені етапи визначають здатність особистості до створення (гіпотезування та генерування), освоєння (концептуалізації та оптимізації) та впровадження (реалізації) нового, що відображає предмет нашого дослідження.

Метою програми-тренінгу розвитку інноваційного потенціалу особистості є стимулювання окремих циклів творчого розв'язання задачі, необхідних у процесі створення інноваційних ідей і їх практичної реалізації, що становить засоби впливу на їхню творчу діяльність. Тренінг спрямований на розвиток творчої спрямованості та здібностей, активізацію інноваційного мислення, а також вміння розв'язувати нові, життєво важливі задачі шляхом зниження рівня стереотипності та шаблонності мислення, а також консерватизму.

Основними завданнями програми-тренінгу $€$ формування таких умінь: 1) самостійно виділяти, ставити й осмислювати проблемну ситуацію; 2) генерувати унікальні ідеї, що сприяють вирішенню визначеної проблеми по-новому; 3) здійснювати пошук концептуальної ідеї серед наявних із вирішення проблеми; 4) оцінювати наявні варіанти й оптимізувати вибір кращого варіанту розв'язку проблеми; 5) розробляти тактичний і стратегічний плани реалізації ідеї.

Програма розвитку інноваційного потенціалу розрахована насамперед на потенційних інноваторів. Однак, за бажанням, до участі у тренінгу можна долучати усіх охочих, у т. ч. студентів-інноваторів (тих, котрі вважають себе інноваторами та мають об'єктивні результати) і студентів-консерваторів (тих, що не вважають себе інноваторами та не мають об'єктивних результатів). До об'єктивних результатів відносимо високі досягнення студентів у науково-інноваційній діяльності (призові місця, нагороди, подяки) й участь у різноманітних інноваційних заходах.

Зміст програми-тренінгу передбачав розгляд теоретичного матеріалу за такими розділами: розділ 1 «нноваційно-творча спрямованість особистості»; розділ 2 «Технології індивідуального генерування інноваційних ідей»; розділ 3 «Концептуалізація інноваційних ідей»; розділ 4 «Формування базису прийняття інноваційних рішень»; розділ 5 «Комерціалізація результатів творчості».

Обсяг тренінгу становить 34 академічні години, з яких: 1) вступна частина - 2 академічні години; 2) основна частина - 30 академічних годин (одне тренінгове заняття - 3 год.); 3) заключна частина - 2 академічні години. Враховуючи просторово-часову організацію процесу навчання студентів у закладі вищої освіти, тренінгові заняття проводилися один раз на тиждень у вільний від занять час.

Вступна частина тренінгу передбачає насамперед знайомство з учасниками, вивчення їхніх очікувань і побажань, а також інформування щодо мети, завдань і змісту тренінгу. Окрім того, у вступній частині тренінгу доцільно визначити організаційні питання (правила роботи, регламент, кількість перерв тощо). Основна частина тренінгу містить ознайомлення $з$ основними теоретичними питаннями конкретного розділу та виконання учасниками запропонованих практичних вправ і завдань. Заключна частина тренінгу передбачає підведення підсумків та оцінювання досягнення поставленої мети та завдань. Слід наголосити, що за подібною логікою (вступна, основна та заключна частини) побудоване кожне тренінгове заняття.

У розробці програми тренінгу використано досвід Г. Альтшуллера [7], Б. Барнета та Д. Еванса [9], Е. де Боно [5], Б. Еберле [6], В.О. Моляко [16], Я.О. Понамарьова [18] та ін. Завдання і вправи, запропоновані для тренінгу, з одного боку, спрямовані на розвиток творчої уяви, винахідливості, а з іншого - на творче вирішення практичних задач, орієнтацію на зовнішню реальність, адже уява забезпечує створення нових оригінальних образів на основі ідейної спрямованості, а практичність допомагає їх втілити у конкретні продукти творчої діяльності.

3 метою розвитку креативного компоненту інноваційного потенціалу особистості доцільно застосовувати такі методики, як: ТРВЗ (теорія розв'язання винахідницьких задач); КАРУС (Комбінування - Аналогізування - Реконструювання - Універсальна стратегія - Спонтанні, тобто випадкові підстановки); SCAMPER (S - замінити; C - комбінувати; А - додати; М - модифікувати / змінити; P - застосувати з іншою метою; E - видалити; $\mathrm{R}$ - переставити / перевернути / змінити порядок); дизайн-мислення та ін.

Структуру розробленої програми представлено у табл. 1

Як видно з табл. 1, першим етапом розвитку креативної компоненти інноваційного 


\section{Структура програми розвитку креативного компоненту} інноваційного потенціалу особистості

\begin{tabular}{|c|c|c|c|}
\hline Розділи & Завдання & Вправи & Години \\
\hline \multicolumn{4}{|c|}{$\begin{array}{l}\text { I ЕТАП. ГІПОТЕЗУВАННЯ } \\
\text { Виявлення і визначення проблеми, пошук фактів, що підтверджують ї̈ існування }\end{array}$} \\
\hline $\begin{array}{l}\text { Розділ 1. Інновацій- } \\
\text { но-творча спрямованість } \\
\text { особистості }\end{array}$ & $\begin{array}{l}\text { формувати вміння самостійно } \\
\text { виділяти, ставити й осмислю- } \\
\text { вати проблемну ситуацію } \\
\end{array}$ & $\begin{array}{l}\text { - } \text { інтуїтивне мислення } \\
\text { - } \text { активне мислення } \\
\text { - латеральне мислення }\end{array}$ & 6 \\
\hline \multicolumn{4}{|c|}{$\begin{array}{l}\text { II ЕТАП. ГЕНЕРУВАННЯ } \\
\text { Породження нових ідей, варіантів, які надають змогу вирішити проблему по-новому }\end{array}$} \\
\hline $\begin{array}{l}\text { Розділ 2. Технології інди- } \\
\text { відуального генерування } \\
\text { інноваційних ідей }\end{array}$ & $\begin{array}{l}\text { формувати вміння генерувати } \\
\text { унікальні ідеї, що сприяють } \\
\text { вирішенню визначеної про- } \\
\text { блеми по-новому }\end{array}$ & $\begin{array}{l}\text { - } \text { дивергентне мислення } \\
\text { - варіативне мислення } \\
\text { - } \quad \text { асоціативне мислення }\end{array}$ & 6 \\
\hline \multicolumn{4}{|c|}{$\begin{array}{l}\text { III ЕТАП. КОНЦЕПТУАЛІЗАЦІЯ } \\
\text { ЗДіЙСНеНнЯ ВИбОрУ із НаявнОГО ПерелікУ іДеЙ ЩОДО вирішення Проблеми }\end{array}$} \\
\hline $\begin{array}{l}\text { Розділ 3. Концептуаліза- } \\
\text { ція інноваційних ідей }\end{array}$ & $\begin{array}{l}\text { формувати вміння здійсню- } \\
\text { вати пошук концептуальної } \\
\text { ідеї серед наявних із вирі- } \\
\text { шення проблеми }\end{array}$ & $\begin{array}{l}\text { - } \text { конвергентне мислення } \\
\text { - логічне мислення } \\
\text { - } \text { концептуальне мислення }\end{array}$ & 6 \\
\hline \multicolumn{4}{|c|}{$\begin{array}{l}\text { IV ETAП. ОПТИМІЗАЦІя } \\
\text { оцінка ідеї, формування критеріїв для пошуку прийняття оптимального рішення }\end{array}$} \\
\hline $\begin{array}{l}\text { Розділ 4. Формування } \\
\text { базису прийняття іннова- } \\
\text { ційних рішень }\end{array}$ & $\begin{array}{l}\text { формувати вміння оцінювати } \\
\text { наявні варіанти й оптимізу- } \\
\text { вати вибір кращого варіанту } \\
\text { розв'язку проблеми }\end{array}$ & $\begin{array}{l}\text { - } \text { альтернативне мислення } \\
\text { - критичне мислення } \\
\text { - діалектичне мислення }\end{array}$ & 6 \\
\hline \multicolumn{4}{|c|}{$\begin{array}{l}\text { V ЕТАП. РЕАЛІЗАЦІя } \\
\text { схвалення та втілені ідеї, планування дій, реалізація задуманого }\end{array}$} \\
\hline $\begin{array}{l}\text { Розділ 5. Комерціалізація } \\
\text { результатів творчості }\end{array}$ & \begin{tabular}{|l} 
формувати вміння розро- \\
бляти тактичний і стратегіч- \\
ний план реалізації ідеї
\end{tabular} & $\begin{array}{ll}\text { - } & \text { рефлексивне мислення } \\
\text { - } & \text { прогностичне мислення } \\
\text { - } & \text { продуктивне мислення }\end{array}$ & 6 \\
\hline \multicolumn{3}{|l|}{ Всього } & 30 \\
\hline
\end{tabular}

потенціалу особистості $€$ «гіпотезування». Як підсвідомий здогад у пошуках вирішення проблеми, пояснення чогось цей етап передбачає висування гіпотези на основі попередніх знань, теорій і наявних фактів із метою передбачення, прогнозування, можливих результатів. У гіпотезі вже орієнтовно відображається первинна відповідь на постановку і створення проблемної ситуації шляхом її спростування, тобто будь-яка гіпотеза потребує доказів. Саме завдяки гіпотезуванню як формі визначення певної проблеми запускається процес формування творчої думки.

Зазначений етап реалізується через змістовий розділ «Інноваційно-творча спрямованість особистості» (6 годин) і включає комплекс вправ, спрямованих на актуалізацію стихійних творчих сил та інтелектуальної ініціативи, зокрема: 1) інтуїтивне мислення; 2) активне мислення; 3) латеральне мислення.

1.1 Інтуїтивне мислення - процес пізнання істини без зумовлень за допомогою доказів, що здійснюється на основі попереднього досвіду [13]. Саме взаємозв'язок пізнання із набутим досвідом допомагає зрозуміти реальність на основі безпосередніх сприймань і відображення дій предметів і явищ об'єктивного світу та висувати нові ідеї. Таке мислення визначається швидкістю протікання, відсутністю чітко виражених етапів, мінімальним усвідомленням, що надає змогу швидко ідентифікувати цінні чи корисні творчі ідеї без свідомої думки. Воно залежить від індивідуального досвіду людини, апперцепції.

1.2 Активне мислення - це здатність піддавати вольовому акту судження, спрямоване на розв'язання задачі; здатність цілеспрямовано використовувати свої розумові здібності для досягнення цілей. Воно проявляється в інтенсивному фокусуванні мислення на конкретному об'єкті чи предметі для досягнення поставлених цілей, тобто визначається інтелектуальною ініціативою. У процесі активного мислення суб'єкт постійно знаходить певні проблемні питання, формулює їх та осмислює, а також намагається вирішити. Усвідомлення проблеми починається з постановки певного питання, у процесі вирішення якого генеруються альтернативи прийняття рішення. Таке мислення визначається здатністю як уважно слухати, так і чітко викладати свої думки.

1.3 Латеральне (горизонтальне, бокове) мислення - це процес опрацювання інформації та породження ідей, який полягає у зміні 
патернів, тобто шаблонів, шляхом вивчення проблеми з різних позицій. Такий нешаблонний спосіб вирішення проблеми, на відміну від логічного мислення, допускає пошук інформації, яка, на перший погляд, не стосується проблеми. Це сприяє руйнуванню стереотипів і знаходженню альтернативних рішень одночасно в декількох напрямах. Як визначає Едвард де Боно [5], особливістю латерального мислення $€$ те, що його результатом $€$ породження таких ідей, які неможливо згенерувати завдяки «вертикальній логіці», тобто логічному мисленню. Саме латеральне мислення надає змогу вирішити проблему шляхом з'ясування причини, що її спричинила, а потім визначити способи її усунення. Як здатність побачити проблему з іншої позиції, бокове мислення породжує нове розуміння, надає змогу застосувати інший шаблон мислення, який до цього не був очевидним.

Варто відзначити, що наприкінці розгляду кожного змістовного розділу програми учасникам пропонується індивідуальне завдання. Зокрема, завдання до розділу 1 - визначити конкретну проблему, над якою учасник планує надалі працювати.

Другим етапом розвитку креативного компоненту інноваційного потенціалу особистості $€$ «генерування». На цьому етапі важливим $\epsilon$ генерування якомога більшої кількості ідей щодо вирішення проблеми, не відкидаючи примітивних чи абсурдних. Саме генерація нетрадиційних і різносторонніх ідей різноманітними способами дає змогу перейти від визначення проблеми до безпосереднього прийняття конкретних рішень.

Зазначений етап реалізується через розділ «Технології індивідуального генерування інноваційних ідей» (6 годин) і включає комплекс вправ, що спрямовані на: 1) дивергентне мислення; 2) варіативне мислення; 3) асоціативне мислення.

2.1 Дивергентне мислення - процес, у якому породжується значна кількість різних ідей на основі висхідних даних шляхом вивчення багатьох можливих варіантів. Саме така варіативність вирішення проблемної ситуації, як визначив Дж. Гілфорд [12], базується на таких особливостях дивергентного мислення, як: оригінальність як своєрідна здатність продукувати незвичний підхід до вирішення проблеми; гнучкість як здатність обмірковувати різні способи вирішення проблемної ситуації шляхом переключення між цими способами; легкість і продуктивність як здатності швидко генерувати декілька ідей; точність як здатність вибирати рішення, що відповідає поставленій меті.

2.2 Варіативне мислення - це процес, який полягає у пошуку можливих варіантів вирішення проблемної ситуації. Таке мислення застосову- ється тоді, коли необхідно: розв'язати задачу з неоднозначною умовою; зіставити різні способи вирішення одного і того самого завдання; зіставити різні інтерпретації одного об'єкта. Особливостями такого мислення є його оригінальність, продуктивність, самостійність і розробленість. Вміння визначати варіанти вирішення будь-якої проблеми призводить до руйнування стереотипів, шаблонів, установок.

2.3. Асоціативне мислення - процес, який полягає у створенні суб'єктивного образу між поняттями й уявленнями, що виникає у процесі їх усвідомлення. Воно передбачає створення асоціацій за суміжністю, схожістю та контрастом. Слід зазначити, що засноване на асоціаціях мислення сприяє як розвитку пам'яті та стимуляції уяви, так і створенню смислових зв'язків і нових оригінальних ідей.

Індивідуальне завдання до змістового розділу: учасникам пропонується згенерувати якомога більше унікальних ідей, що вирішують проблему, визначену під час вивчення попереднього розділу.

Третій етапом розвитку креативного компоненту інноваційного потенціалу особистості $€$ «концептуалізація». На цьому етапі здійснюється когнітивна обробка наявних ідей, що полягає у осмисленні, оцінюванні й обґрунтованому відборі пріоритетного варіанту вирішення проблеми з позиції корисності, цінності для бізнесу та технічних можливостей.

Зазначений етап реалізується через змістовий розділ «Концептуалізація інноваційних ідей» (6 годин) і включає комплекс вправ, спрямованих на: 1) конвергентне мислення; 2) логічне мислення; 3) концептуальне мислення.

3. 1 Конвергентне мислення - лінійний процес, що базується на послідовному виконанні завдання за заданим алгоритмом і спрямований на визначення одного правильного варіанту його розв'язку. За конвергентного мислення суб'єкт фокусується на ретельному аналізі різноманітних пропозицій-варіантів, зіставляє їх та обирає кращий із них. Воно пов'язне з аналізом, судженням і прийняттям рішень, а також із застосуванням наявних знань. Як інструмент вирішення творчих завдань, конвергентне мислення полягає у раціональному відборі ідеї з метою прийняття оптимального рішення.

3.2. Логічне мислення - це процес, який полягає у послідовному міркуванні 3 метою встановлення причинно-наслідкових зв'язків. Воно дає змогу об'єктивно вивчити проблему та зробити раціональний висновок. Саме логічне мислення сприяє знаходженню зв'язків між предметами та явищами, формуванню думок і умовиводів за допомогою логічних операцій (аналізу, синтезу, порівняння, узагальнення та ін.) у послідовній формі. 
3.3 Концептуальне мислення - цілеспрямований процес, який у описі певного об'єкта відображає його зміст і сенс. Суб'єкт чітко усвідомлює, що потрібно обмірковувати та з якою метою. Таке мислення передбачає створення певної концепції шляхом об'єктивного аналізу: висхідної ситуації (що є станом на цей момент), мети (що є бажаним результатом), сукупності прийомів (як отримати очікуваний результат). У процесі такого створення концепції структуризується сам процес мислення, а наміри суб'єкта стають явними.

Індивідуальне завдання до змістового розділу: учасникам пропонується вибрати одну концептуальну із запропонованих раніше унікальних ідей вирішення поставленої проблеми.

Четвертим етапом розвитку креативної компоненти інноваційного потенціалу особистості $€$ «оптимізація». На цьому етапі відбувається оцінювання концепції продукту та шляхів його покращення (вдосконалення), внаслідок чого приймається рішення про оптимальний спосіб його реалізації, тобто конкретизуються та деталізуються дослідницькі ідеї. Саме на етапі оптимізації формується чіткіше уявлення про продукт, проблеми, які можуть виникнути під час його впровадження.

Зазначений етап реалізується через змістовий розділ “Формування базису прийняття управлінських рішень" (6 годин) і включає комплекс вправ, що спрямовані на: 1) альтернативне мислення; 2) критичне мислення; 3) активне мислення.

4.1. Альтернативне мислення - це процес, який полягає у здатності розробляти різноманітні стратегії розв'язку задачі шляхом виявлення можливих альтернатив. Це мислення застосовується тоді, коли виникають певні труднощі на шляху до досягнення мети, що потребує пошуку інших варіантів розв'язку проблеми. Воно дає змогу поставити під сумнів певне рішення, дати відповіді на несподівані запитання, мінімізувати вплив проблем. Як процес удосконалення, альтернативне мислення базується на здатності розуміти та приймати інші думки (протилежні), відмінні від власної. Результатом такого мислення $€$ конструктивне вирішення задачі. Цілеспрямований пошук альтернативних поглядів на певну ситуацію $є$ важливим творчим проявом.

4.2. Критичне мислення - це процес, який полягає у здатності ставити під сумнів загальновизнане й аргументувати це. Критичне розмірковування як формулювання припущень щодо розв'язку проблемної ситуації визначається здатністю мислити цілеспрямовано, раціонально, логічно та гнучко. Критичне мислення передбачає об'єктивне розмірковування над проблемою, наведення різносторонніх аргументів із певної проблеми, обґрун- тування й оцінювання аргументів, їхніх сильних і слабких сторін. Саме критичне мислення $€$ важливим інструментом для прийняття оптимальних рішень, оскільки воно базується на аргументованих висновках.

4.3. Діалектичне мислення - це процес, що полягає у здатності знаходити, сприймати та зіставляти суперечності, тобто бачити явище у єдності суперечностей. Протилежні позиції можуть як співіснувати, так і поєднуватися, у процесі чого виникає нове знання, тобто діалектичне мислення застосовує як «і», так і «але». Воно дає змогу розглядати проблеми з різних позицій і досягати узгодження. Діалектичне мислення відіграє вагому роль у збалансованому прийнятті рішень, оскільки його результатом $\epsilon$ конструювання нового способу вирішення суперечностей.

Індивідуальне завдання до змістовного розділу: учасникам пропонується оцінити варіанти покращення ідеї-концепції, запропонованої напередодні, та вибрати кращий варіант.

П'ятим етапом розвитку креативної компоненти інноваційного потенціалу особистості $\epsilon$ «реалізація». На цьому етапі створюється і впроваджується прийняте на попередньому етапі рішення шляхом розробки тактичного та стратегічного плану реалізації ідеї. Результатом цього етапу $€$ створення прототипів. Саме створення прототипів дає змогу відповісти на запитання, чи є ця ідея корисною, тобто перевірити свою ідею та прислухатися до оцінки результатів.

Зазначений етап реалізується через змістовий розділ “Комерціалізація результатів творчості» (6 годин) і містить комплекс вправ, спрямованих на: 1) рефлексивне мислення; 2) прогностичне мислення; 3) продуктивне мислення.

5.1. Рефлексивне мислення - це процес, який полягає в осмисленні та переосмисленні стереотипів досвіду, на основі інтерпретації яких утворюються нові ідеї чи задуми. Як розміркування, рефлексивне мислення дає змогу суб'єкту усвідомити й обґрунтувати власну та чужу поведінки «очима інших». Таке мислення сприяє перетворенню особистістю власного досвіду шляхом вивчення попередніх уявлень та аналізу подальших дій. Саме рефлексивне мислення шляхом усвідомлення досвіду дозволяє переосмислити певну ситуацію та спланувати різноманітні шляхи її розвитку.

5.3. Продуктивне мислення - це процес знаходження зв'язків між предметами та явищами, внаслідок осмислення якого з'являються нові життєві смисли. Це мислення $€$ поєднанням як креативного, так і критичного та передбачає як опору на минулий досвід, так і вихід за його межі, що сприяє спонтанному породженню нових знань. У процесі такого 
мислення щось змінюється та продукується, тобто може визначатися новизною. Результатом такого мислення $€$ глибинне та швидке засвоєння знань і їх застосування на практиці за нових умов. Воно вирізняється конкретністю формулювання думок, тобто конкретних намірів. У цьому сенсі мислити продуктивно розуміється як здатність думати про те, що треба, як треба та коли треба. Продуктивне мислення відіграє важливу роль у вирішенні важливих питань, оскільки дозволяє спланувати дії та думати про те, що необхідно в певний момент.

Індивідуальне завдання до змістового розділу: учасникам пропонується спланувати конкретні дії щодо реалізації задуманої ідеї-концепції.

Слід наголосити, що всі п'ять змістових розділів пронизані індивідуальними завданнями, оскільки кінцевим результатом тренінгу повинен стати маркетинговий план комерціалізації конкретної ідеї або запропонований процес виготовлення пробної партії інноваційного продукту. Окрім того, на заключній частині тренінгу учасникам пропонується згенерувати та запропонувати шляхи реалізації власної ідеї на основі такої методології вирішення інженерних задач, як дизайн-мислення.

Базуючись на творчому підході, дизайн-мислення передбачає творчий спосіб мислення як сукупність когнітивних, практичних і стратегічних процесів, за допомогою якого розробляють неочікувані ідеї та інноваційні рішення. Таке мислення охоплює п'ять послідовних етапів: 1) емпатію (аналізування контексту, фокусування на тому, що задовольнить потреби та бажання клієнтів); 2) визначення проблеми (пошук і постановку проблемного завдання); 3) генерування ідей (створення якомога більшої кількості варіантів рішення проблеми); 4) протопитування (вибір найкращої ідей і створення прототипів); 5) тестування (реалізація прийнятого рішення й оцінювання результатів) [9].

Наприкінці зазначимо, що практична імплементація розробленої програми дала змогу простежити кількісні та якісні зміни креативного компоненту інноваційного потенціалу у досліджуваних експериментальної групи. Спостерігаючи за ними під час проведення тренінгу, можна відзначити, що вони критично сприймали подану інформацію: ставили багато запитань, шукали різні аргументи, пропонували значну кількість альтернатив вирішення завдання, самостійно приймали рішення та переконливо їх обґрунтовували. Вони вважають, що зміни та нововведення $€$ важливою умовою розвитку суспільства, а тому вбачають необхідність у створенні чогось нового, значущого для суспільства.

Висновки з проведеного дослідження. Отримані результати дають підстави зробити висновок про те, що креативний компонент Є невід'ємною частиною розвитку інноваційного потенціалу особистості, починаючи від визначення певної проблеми, породження унікальної ідеї до її втілення на практиці. Апробація розробленої програми розвитку креативного компоненту інноваційного потенціалу серед майбутніх інженерів дозволяє стверджувати, що вона є ефективною.

Подальшого теоретичного осмислення й емпіричної перевірки потребує питання розробки тренінгових методик із метою розвитку мотиваційного, когнітивного, емоційно-вольового та регулятивного компонентів інноваційного потенціалу особистості.

\section{ЛITEPATУРA:}

1. Basadur M. Leading others to think innovatively together: Creative leadership. The Leadership Quarterly. 2004. № 15 (1). P. 103-121.

2. Basadur M., Gelade G., Basadur T. Creative Problem-Solving Process Styles, Cognitive Work Demands, and Organizational Adaptability. The Journal of Applied Behavioral Science. 2013. № 50 (1). P. 78-113.

3. Bokovets O. Internal resources of studentsinnovators. European Journal of Education and Applied Psychology. 2020. № 2. P. 40-44.

4. Campos H.M. Understanding employees entrepreneurial alertness: The role of creativity and support for creativity. Academy of Entrepreneurship Journal. 2018. № 24 (1).

5. De Bono E. Lateral thinking: creativity step by step. Harper \& Row. 1970.

6. Eberle B. Scamper: Games for Imagination Development. Prufrock Press Inc. 1996.

7. Альтшуллер Г. Найти идею: Введение в ТРИЗ - теорию решения изобретательских задач. Москва : Альпина Паблишер. 2020. 402 с.

8. Артюхова Т.Ю. Возможности развития инновационного потенциала студентов в условиях университета. Теория и практика современной науки. 2016. № 12-2 (18). C. 623-628.

9. Бартнет Б., Еванс Д. Дизайн-мислення. Спроектуй своє життя. Київ : Наш Формат. 2018. 224 с.

10. Батоврина Е.В., Блохина М.С. Развитие инновационного мышления персонала в процессе профессиональной подготовки. Вестник Нижегородского университета им. Н.И. Лобачевского. Серия: Социальные науки. 2017. № 4 (48). С. 126-134.

11. Волянюк Н.Ю., Ложкін Г.В., Колосов А.Б., Андрійцев Б.В. Психологія наукової діяльності : монограсрія. Київ : КПІ ім. Ігоря Сікорського; Центр ДЗК, 2020. 352 с.

12. Гилфрорд Дж. Три стороны интеллекта: психология мышления. Москва : Эксмо, 2008. 437 с.

13. Коваленко А.Б. Психологія розуміння. Київ, 1999.

14. Котлярова Н.Г. Развитие инновационной личности в образовательном процессе. Вестник ЮУрГУ. Серия «Образование. Педагогические науки». 2014. T. 6. № 2. С. 84-91. 
15. Михайлова О.Б. Психология становления инновационного потенциала личности : монограсрия. Москва : РУДН, 2013.

16. Моляко В.О. Стратегії творчої діяльності: школа В.О. Моляко. Київ : «Освіта України», 2008. 702 с.

17. Пахно И.В., Терехова Т.А. Развитие инновационного потенциала личности в социально-психологическом тренинге. Психология в России и за рубежом: материалы I Междунар. науч. конфр. (г. Санкт-Петербург, октябрь 2011 г.). Санкт-Петербург : Реноме, 2011. С. 82-86.
18. Пономарев Я.А. Психология творчества и педагогика. Москва : Педагогика, 1976. 280 с.

19. Шемелина О.С., Быкова Е.С. Социально психологический тренинг как инструмент развития инновативных качеств личности. Профеессиональное образование в современном мире. 2019. № 9 (2). C. 2814-2822.

20. Шмелёва Е.А. Развитие инновационного потенциала личности в научно-образовательной среде педагогического вуза : авторефр. дис. ... докт. психол. наук : 19.00.07. Нижний Новгород, 2013. 